\title{
Phytochemistry and Toxicity Studies of Telfairia Occidentalis Aqueous Leaves Extract on Liver Biochemical Indices in Wistar Rats
}

\author{
Ekpenyong C. E*, Akpan E. E, Udoh N. S \\ Department of Phy siology, College of Health Sciences, University of Uyo, Akwalbom State, Nigeria
}

\begin{abstract}
This study assessed the effect of oral administration of aqueous extract of Telfairiaoccidentalis (TO) leaves on liver biochemical indices in Wistar albino rats. Fifty rats weighing 150-200g were divided into 2 groups A and B, to test for acute (10 days) and sub-acute (4 weeks) effect respectively. Each group consisted of 25 rats, which were further divided into 5 sub-groups 1, 2, 3, 4 and 5. Sub-group 1 served as control and was orally gavaged with standard animal feed only, while sub-groups 2, 3, 4 and 5 were the test groups. In addition to the standard animal feed, $500 \mathrm{mg} / \mathrm{kg}, 1000 \mathrm{mg} / \mathrm{kg}$, $2000 \mathrm{mg} / \mathrm{kg}$ and $4000 \mathrm{mg} / \mathrm{kg}$ of the extract was orally gavaged to the test groups $2,3,4$ and 5 respectively. The standard animal feed given to the control and test groups contained the same amount of daily calories and protein. The acute and sub-acute administration of the extract caused significant differences in values of Aspartate amino Transferase(AST), Aspartate to Alanine amino Transferase(AST/ALT) ratio, Total protein, Albumin, Globulin, Albumin/Globulin ratio, Total body weight, Total and Conjugated bilirubin $(\mathrm{P}<0.001)$ between test and control groups. Seru m levels of other parameters were statistically non-significant. There was no obvious evidence of hepato-toxic ity detected in this study.
\end{abstract}

Keywords TelfairiaOccidentalis Leaves Extract, Hepatoxicity, Rats

\section{Introduction}

As the acceptance of herbal remedy is gradually increasing worldwide[1], there is a growing concern about the hepatotoxicity of several hundreds of dietary herbs/vegetables which have re mained either un-investigated or poorly investigated, and are increasingly used by patients with liver diseases[2]. Paradoxically, so me herbal remedies used in the treatment of liver diseases may be hepatotoxic themselves[3], and at times the specific hepatotoxic component is not known because of the difficulty in proper analysis of the product or plant material. It has been difficult diagnosing herbal hepatotoxicity especially if unsuspected, because consumers generally consider herbal remed ies to be safe and more effective and view them as natural alternatives to orthodox medicine.[3]. A recent report has shown that only $40 \%$ of people who use herbal medic ine informed their primary care physicians [4]. Apart from the safety and the acclaimed therapeutic efficacy, other reasons for the recent surge in the consumption of herbal remedies include easy accessibility, more acceptability from cultural and spiritual perspectives [5], non-involvement of expert consultation and

* Corresponding author:

chrisvon200@yahoo.com (Ekpenyong C. E)

Published online at http://journal.sapub.org/ajmms

Copyright (C) 2012 Scientific \& Academic Publishing. All Rights Reserved inadequacies of primary health care services.

As the use of herbal remedy is increasing, several hundreds of plants and herbs which initially were considered to be safe and therefore extensively consumed are now showing some toxic manifestations in some vital organs such as the skin, heart, kidney, brain and liver especially on prolonged ingestion, raw usage and/ or repeated exposure. These have all been reported[6]. A typical example is the Chinese herbal product "Jin Bu Huan", which has been used for more than 1000 years for its sedative, analgesic and antispasmodic properties in a previously non-toxic herbal remedy[3], and was there after discovered to possess acute and chronic hepatotoxic potentials with a resultant chronic hepatitis and liver fibrosis after it use[7].

An increasing body of evidence shows that factors such as variability in active/toxic ingredients, over dose, prolonged used/abused, drug-herb interactions, coexisting disease and idiosyncratic reactions like allergy, hepatitis and anaphylaxis could account for these unusual hepatotoxic effects. Others include manufacturing and quality problems such as adulteration, misidentification, substitution of one herb with another, variability in the amount of active ingredients, lack of accurate identifying labels, contaminants, improper processing and preparation of the herbal products (e.g. raw usage). In the liver, the spectrum of disorders may range from mild elevation of hepatic enzy mes to fulminant liver failure requiring liver transplantation[8]. A lso, the spectrum 
of injury may range from acute hepatitis, sub acute hepatic necrosis, cholestatic hepatitis, cirrhosis and acute liver failure[3,9].Several mechanis ms have been postulated as being the possible processes through which these herbal remedies cause liver injury or dysfunctions. These include inhibition of cyclo-oxygenase and/or cytochrome p450 activity or an immune mediated liver in jury[10].

However, the hepato-protective effects of some botanicals have also been confirmed by clinical research and their use in prevention and treatment of liver diseases supported. A typical example is the Silybummarianum, which is currently the most well researched plant in the treatment of liver disease in many countries including Germany. The hepato-protective effects of Silymarin in human after mushroom poisoning (Amanita spp) have been repeatedly demonstrated and confirmed[11]. In the light of these, continuous research to reappraise the acclaimed hepato-protective/toxic effects in some of the extensively consumed herbs/vegetables is recommended. Prior studies have shown that these dietary vegetables/herbs are the common sources of drug induced liver injury. Thus, this research work evaluates the acute and sub-acute effect of TO leaves extract on rat liver biochemical indices since it is such a widely consumed vegetable in Nigeria, most sub Saharan African countries, and worldwide.

Telfairiaoccidentalis (Fluted Pumpkin) is a leaf and seed vegetable from the tribe of Joliffieae of the sub-family Cucurbitaceae. Nutritionally, the leaves of this herb are rich in minerals such as iron, potassium, sodium, phosphorus, calcium and magnesium. Antioxidants such as thiamine, riboflavin,nicotinamide, ascorbic acid and amino acids such as alanine, aspartate, glycine, leucine, etc are also found[12, 13]. It is used in treatment of anemia, convulsion, atherosclerotic cardiovascular disorders, high blood pressure, hyperglycemia, dyslipidemia, arthritis, liver problems and inflammatory conditions.[14-18].Phytochemically, it contains tannins, hence it purgative,anti-asthmatic, antitussives and anti hay fever effect[19-21]. Others include terpenoids an anti-feedant with insecticidal property[20, 21]. Flavanoids and saponins are also present[21].

We hope the results of this research will provide additional and useful information about the effect of this widely consumed vegetable on the liver bio-chemical indices.

\section{Materials and Methods}

\section{Collection and identification of plant materials}

Fresh leaves of $T O$ were obtained from the agricultural farm in Uyo Local Government Area in Akwalbom State, Nigeria. A Taxonomist in the Department of Botany, University of Uyo, Nigeria, identified the leaves.

\section{Preparation of Telfairiaoccidentalis aqueous leaves} extract

The fresh leaves were rinsed to remove sand and other debris, oven dried at $40^{\circ} \mathrm{c}$ and pulverized into powder using electric blender to give a gram weight of $865 \mathrm{~g}$. This was soaked in 2 liters of distilled water and allowed overnight for about 12 hours and stirred at intervals. The mixture was sieved with a clean white cloth. The filtrate was dried by heating in water bath at $40^{\circ} \mathrm{c}$ to obtain a solid extract. The solid extract was weighed with an electronic weighing balance (OHAUS) before the stock solution was prepared. The stock solution was prepared by dissolving $15 \mathrm{~g}$ of extract in $10 \mathrm{ml}$ of water to give concentration of $1500 \mathrm{mg} / \mathrm{ml}$. The solution was well labeled and preserved in a refrigerator at $4^{\circ} \mathrm{c}$ until required for use.

Phytochemical screening of Telfairiaoccidentalis leaves extracts

One hundred grams (100g) of the blended leaves was soaked in $500 \mathrm{ml}$ of $95 \%$ ethanol in a sterile conical flask and stored at room temperature and thereafter filtered using a Whatman No 2 filter paper. The filtrate was evaporated to dryness and preserved in clean bottles at room temperature until required for used.

The phytochemical analys is of the extract was carried out to determine the presence of saponins, phenolics, alkaloids, tannin, flavonoids, glycosides, steroids, deoxysugar, terpens and anthraquinone using standard procedures according to Trease and Evans[22] and Sofowora[23].

Deter mination of the presence of anti-nutrients

One hundred grams $(100 \mathrm{~g})$ of the extract $T O$ leaves was used to determine the presence of some anti-nutrients such as tannin, oxalate, cyanide and phytate.

The presence of tannic acid (a polyphenol) was determined using the method described by Makkar and Goodchild[24]. The hydrogen cyanide was determined using the method described by Fasuyi et al[13]. The presence of phytate was determined as described by Young and Greaves[25]. The presence of oxalate was determined by the titrimetric method of Moir[26] as modified by Ranjhan and Krishna[27].

\section{Collection and mainte nance of animals}

Fifty adult male Wistar albino rats weighing 150-200g were obtained from the animal house of the Faculty of Basic Medical Sciences, University of Uyo, Nigeria. Their initial weights noted and they were divided into two groups A and B. Each group consisting of twenty-five rats of 5 sub-group: $1,2,3,4$ and 5 with five rats per subgroup. Subgroup 1 in each group served as the control.

They were housed in a standard wooden cage with wooden shavings as their beddings, kept and maintained in the animal house of Faculty of Basic Medical Sciences, University of Uyo for one week prior to the study to allow for acclimatization. They had free access to water ad lib itum and good light source and maintained at room temperature.

\section{Deter mination of $\mathbf{L D}_{\mathbf{5 0}}$}

Lethality studies to determine the $\mathrm{LD}_{50}$ was performed according to the procedure described by Lorke[28]. Twenty rats weighing $150-200 \mathrm{~g}$ were rando mly divided into 5 groups with each group having 4 rats. They were treated with 1000 , $2000,3000,4000$ and $5000 \mathrm{mg} / \mathrm{kg}$ respectively with no mortality recorded after 24 hours. In the second phase, doses of 5500,5750 and $6000 \mathrm{mg} / \mathrm{kg}$ produce negative behavioral 
changes followed by $100 \%$ mortality at $5500 \mathrm{mg} / \mathrm{kg}$ concentration of the extract. The median lethal dose $\left(\mathrm{LD}_{50}\right)$ was then calculated as follows:

$\mathrm{LD}_{50}=\sqrt{ } \mathrm{D}_{\mathrm{o}} \times \mathrm{D}_{100}$

$\mathrm{D}_{\mathrm{o}}=$ Maximum dose that produce $0 \%$ mortality

$\mathrm{D}_{100}=$ Minimum dose that produce $100 \%$ mortality

$\mathrm{LD}_{50}=\sqrt{ } 5000 \times 5500=5244.04 \mathrm{mg} / \mathrm{kg}$

From here, convenient doses were chosen to preclude the lethal range.

\section{Adminis tration of extr act}

Animals in subgroup 1 (control) in both groups were orally gavaged with standard animal feed (Bendel Feed and Flour Mill Ltd. Benin) only, while those in subgroups 2, 3, 4 and 5 (test groups) in addition to the standard animal feed, were orally gavaged with $500 \mathrm{mg} / \mathrm{kg}, \quad 1000 \mathrm{mg} / \mathrm{kg}, 2000 \mathrm{mg} / \mathrm{kg}$, and $4000 \mathrm{mg} / \mathrm{kg}$ body weight of the extract respectively. The different doses were chosen based on the $\operatorname{LD}_{50}(5244.04 \mathrm{mg} / \mathrm{kg})$ to preclude the lethal dose. The standard animal feed given to the control and test groups contained the same amount of daily calories and protein.

\section{Blood s ample collection}

After 10 days of extract administration, all animals in-group A were weighed again and the sacrificed after being anaesthsized. Dissection to expose the heart was performed and blood was obtained through cardiac puncture into specimen bottles with no anticoagulant. The samples were analyzed in the Chemical Pathology Unit of the University of Uyo Teaching Hospital to test for the acute effect of the extract on liver biochemical indices. The liver of each rat was removed and the weight noted.

Similar procedures were repeated for the experimental animals in group B after four weeks of extract administration and tested for sub-acute effect. The research protocols were carried out in the University of Uyo, according to the rules in Nigeria (Revised Hels in ki Declaration, 2008) governing the use of laboratory animals as acceptable internationally.

\section{Ass ay of biochemical parameters}

Determination of serum AST, ALT and ALP: serum levels of these enzymes were determined using appropriate test kits (Randox Laboratories U.K).

Serum assay for AST and ALT: were determined according to the procedure described by Segal and Matsuzawa[29] The principle of the method for measuring ALT involved monitoring the concentration of pyruvate hydrazone formed with 2, 4, dinitrophenyl hydrazine, while for AST, it involved monitoring the concentrations of oxaloacetate hydrazone formed with 2, 4 dinitrophenyl hydrazine.

Alkaline phosphatase: (ALP) was determined by the method of Ahamed and King[30].

Serum total protein: was estimated using the Biuret method based on the principle that protein react with copper (II) to produce a blue-violet color compound in alkaline medium and that the color intensity is proportional to the concentration of the total protein in the sample.

Serum albumin concentration was estimated using the albumin-bro mocresol green reaction. (BCG) as described by Doumas et al[31]. The principle is based on the albumin quantitatively binding to the indicator 3, 3'5, 5', tetra-bromo-m-cresol sulphonaphthalein (bro mocresol green) which absorb maximally at $578 \mathrm{~nm}$.

Seru $m$ total and conjugated bilirub in was estimated using colorimetric method.

\section{Statis tical Analysis}

Descriptive statistics was computed for each of the liver function indices and reported as means \pm standard deviation. Furthermore, one-way analys is of variances (ANOVA) was used to compare differences in liver function indices of rats following the administration of different concentration of $T O$ leaves extract. Post analys is to determine the groups that differs significantly from each other was performed using the Least Significance DifferenceTest (LSD).

All statistical analysis were enhanced using the statistical package for social sciences version 17 (SPSS 17.0) and $\mathrm{P}<$ 0.05 was considered to be statistically significant.

\section{Results}

Table 1 shows the phytochemical constituents of TO leaves extract to include: saponin, tannin, flavoniods and phenolics.

Table 1. Phytochemical const ituents of Telfairiaoccidentalis leaves extract

\begin{tabular}{|c|c|}
\hline PHYT OCHEMICAL CONST ITUENTS & EXT RACT \\
\hline SAPONIN & ++ \\
\hline TANNIN & + \\
\hline TERPENS & - \\
\hline ANTHRAQUINONE & - \\
\hline DEOXYSUGARS & - \\
\hline STEROIDS & - \\
\hline FLAVANOIDS & + \\
\hline ALKALOIDS & + \\
\hline PHENOLIC & + \\
\hline
\end{tabular}

Key

$$
\begin{aligned}
& ++=\text { marked } \\
& +=\text { Present } \\
& \text { - = Absent }
\end{aligned}
$$

Table 2 shows the anti-nutrient content to include tannin, hydrogen cyanide, phytic acid and oxalate.

Table 3 shows that acute administration of TO leaves extract on experimental animals caused a non-significant differences in ALP $($ Fcal $=2.51, \mathrm{P}=0.074)$, ALT $($ Fcal $=$ $2.68, \mathrm{P}=0.061)$, Albumin $($ Fcal $=2.40, \mathrm{P}=0.084)$, Liver weight $(\mathrm{Fcal}=0.83, \mathrm{P}=0.524)$ and ratio of liver to body weight $($ Fcal $=1.04, P=0.414)$. However, significant differences in levels of ALT $($ Fcal $=33.02, \mathrm{P}<0.001)$, Total protein $(\mathrm{Fcal}=329.53, \mathrm{P}<0.001)$, Globulin $(\mathrm{Fcal}=13.54, \mathrm{P}$ $<0.001)$, Total bilirubine $($ Fcal $=47.65, \mathrm{P}<0.001)$, Conjugated bilirubin (Fcal $=34.25, \mathrm{P}<0.001)$ and Albumin/globulin ratio $(\mathrm{Fcal}=32.85, \mathrm{P}<0.001)$ were obtained between test and control groups. Group 5 had the highest level of AST, total protein, globulin and total bilirubin, while group 3 had the highest body weight.

Table 4 shows that sub-acute administration of extract 
caused significant differences in AST (Fcal $=33.18, \mathrm{P}<$ $0.001)$, Total protein $(\mathrm{Fcal}=424.24, \mathrm{P}<0.001)$, Albumin $($ Fcal $=111.204, \mathrm{P}<0.001)$, Globulin $($ Fcal $=128.85, \mathrm{P}<$ $0.001)$, Liver weight $(\mathrm{Fcal}=21.33, \mathrm{P}<0.001)$, Body weight $($ Fcal $=14.05, \mathrm{P}<0.001)$, Total bilirubin $(\mathrm{Fcal}=18.510, \mathrm{P}<$ $0.001)$ and conjugated bilirubin $(\mathrm{Fcal}=130.71, \mathrm{P}<0.001)$ between control and test groups. Group 5 recorded the highest levels of AST and total protein. Results of other indices were non-significant.

Appropriate post analys is to determine which groups were different from each other in the effect of the extract on serum liver biochemical indices following the 10 days administration showed non-significant differences in serum levels of AST between groups 2 and 3, 2 and 4, 3 and 4 and 3 and 5 with $\mathrm{P}=0.069,0.221,0.519$ and 0.144 respectively. However, significant differences were detected in other groups. Significant serum levels of total protein were also detected in all studied groups, whereas ALB/G ratio differs significantly among groups with the exception of between group 1 and $2(\mathrm{P}=0.576)$ and 2 and $3(\mathrm{P}=0.627)$.

Total and conjugated bilirubin levels showed non-significant differences between groups 1and 2, 2 and 3, 2 and 4 with $P=0.818,0.059$, and 0.940 and groups 1 and 2 , 3 and 4,2 and 5, 1 and 3 , and 3 and 5 with $P=0.818,0.474$,
$0.542,0.155,0.186$ and 0.914 respectively. Significant differences were detected in other groups $(\mathrm{P}<0.005)$.

Also, total body weight was significantly different between groups 1 and 5, 2 and 5, 4 and 5, and 3 and 5 with $P$ $=0.001,0.009,0.042$ and 0.001 respectively.

Pair wise comparison of the effectsfollowing 4 weeks administration of the extract showed that, the serum levels of AST was significantly different between all paired groups except groups 3 and $5(\mathrm{P}=0.578)$. Similarly, total serum protein and albumin fractions were significantly different in all groups with $(\mathrm{P}<0.05)$. Significant levels of globulin was detected in all paired groups with exception of group 1 and 3 , 2 and 3 and 4 and 5 with $P=0.093,0.262$ and 0.164 respectively. ALB/Gratio also showed significant differences between the paired groups except group 1 and 2 $(\mathrm{P}=0.805)$ and group 2 and $5(\mathrm{P}=0.925)$. Significant levels in total bilirubin was detected in other paired groups except groups 1 and $4(\mathrm{P}=0.199)$ and 3 and $5(\mathrm{P}=0.653)$. In addition, significant differences in body weight was detected in otherpaired groups at $(\mathrm{P}<0.005)$ except groups 1 and $2(\mathrm{P}$ $=0.237), 1$ and $3(\mathrm{P}=0.999), 1$ and $5(\mathrm{P}=0.341)$ and 1 and 4 $(\mathrm{P}=0.341)$. Similarly, Liver/Body weight ratio was significant in other groups excerpt 1 and 2 and 2 and 5 with $P$ $=0.205$ and 0.761 respectively.

Table 2. Anti-nutrient const ituents of $100 \mathrm{~g}$ of Telfairiaoccidentalis leaves extract

\begin{tabular}{|c|c|c|c|}
\hline TANNIN mg/100g & CYANIDE mg/100g & PHYTIC ACID mg/100g & OXALATE mg/100g \\
\hline $35.0 \pm 0.03$ & $50.10 \pm 0.1$ & $85.06 \pm 0.1$ & $68.20 \pm 0.02$ \\
\hline
\end{tabular}

Table 3. Effect of acute (10 days) administration of $T$. Occidentalis leaves extract on some liver biochemical indices in rats

\begin{tabular}{|c|c|c|c|c|c|c|c|}
\hline \multirow[b]{2}{*}{ INDICES } & \multirow{2}{*}{$\begin{array}{c}\text { GROUP-1 } \\
(\text { CONT ROL }) \\
(\mathrm{n}=5)\end{array}$} & \multicolumn{4}{|c|}{ GROUPS } & \multirow[b]{2}{*}{$\mathrm{F}$} & \multirow[b]{2}{*}{ P-VALUE } \\
\hline & & $\begin{array}{r}\text { GROUP - } 2 \\
(500 \mathrm{mg} / \mathrm{kg})\end{array}$ & $\begin{array}{l}\text { GROUP - } 3 \\
(1000 \mathrm{mg} / \mathrm{kg})\end{array}$ & $\begin{array}{l}\text { GROUP - } 4 \\
(2000 \mathrm{mg} / \mathrm{kg})\end{array}$ & $\begin{array}{l}\text { GROUP - } 5 \\
(4000 \mathrm{mg} / \mathrm{kg})\end{array}$ & & \\
\hline $\operatorname{AST}(\mu / L)$ & $11.61 \pm 0.24$ & $16.91 \pm 1.58$ & $18.37 \pm 0.08$ & $17.87 \pm 0.03$ & $19.52 \pm 2.15$ & 33.02 & $<0.001$ \\
\hline $\operatorname{ALP}(\mu / L)$ & $48.38 \pm 0.85$ & $48.72 \pm 0.66$ & $52.76 \pm 0.67$ & $49.90 \pm 0.89$ & $51.40 \pm 1.94$ & 2.51 & 0.074 \\
\hline AST/ALT RATIO & $0.73 \pm 0.16$ & $0.88 \pm 0.09$ & $0.97 \pm 0.02$ & $0.95 \pm 0.01$ & $1.02 \pm 0.13$ & 6.69 & 0.001 \\
\hline TOTAL PROTEIN g/L & $40.20 \pm 0.84$ & $50.66 \pm 0.45$ & $55.56 \pm 0.44$ & $62.40 \pm 0.89$ & $68.57 \pm 1.12$ & 329.53 & $<0.001$ \\
\hline ALBUMIN g/L & $26.17 \pm 0.82$ & $27.35 \pm 0.56$ & $29.20 \pm 2.28$ & $38.60 \pm 3.36$ & $47.20 \pm 0.83$ & 111.204 & $<0.001$ \\
\hline GLOBULIN g/L & $26.42 \pm 0.48$ & $26.65 \pm 0.46$ & $26.89 \pm 0.92$ & $28.05 \pm 1.48$ & $30.70 \pm 1.23$ & 13.54 & $<0.001$ \\
\hline TOTAL BIL. $(\mu \mathrm{mol} / \mathrm{L})$ & $8.10 \pm 0.10$ & $8.18 \pm 0.28$ & $10.24 \pm 0.76$ & $9.53 \pm 0.83$ & $12.28 \pm 0.44$ & 47.65 & $<0.001$ \\
\hline CONJ. BIL. $(\mu \mathrm{mol} / \mathrm{L})$ & $3.74 \pm 0.42$ & $3.90 \pm 0.10$ & $4.06 \pm 0.19$ & $5.94 \pm 0.61$ & $4.04 \pm 0.04$ & 34.25 & $<0.001$ \\
\hline BODY WEIGHT $\mathrm{g}$ & $159.31 \pm 0.83$ & $158.69 \pm 0.84$ & $157.00 \pm 1.22$ & $158.27 \pm 0.82$ & $156.33 \pm 0.85$ & 5.360 & 0.004 \\
\hline LIVER WEIGHT g & $3.64 \pm 0.05$ & $3.57 \pm 0.14$ & $3.52 \pm 0.90$ & $3.58 \pm 0.11$ & $3.59 \pm 0.11$ & 0.83 & 0.524 \\
\hline $\begin{array}{c}\text { LIVER WEIGHT / } \\
\text { BODY WEIGHT } \\
\text { RAT IO }\end{array}$ & $0.0228 \pm 0.0003$ & $\begin{array}{c}0.0225 \pm \\
0.0009\end{array}$ & $\begin{array}{c}0.02251 \pm \\
0.0006\end{array}$ & $\begin{array}{c}0.02269 \pm \\
0.0007\end{array}$ & $\begin{array}{c}0.0225 \pm \\
0.0008\end{array}$ & 0.197 & 0.937 \\
\hline
\end{tabular}

$\mathrm{P}<0.05$ was considered statistically significant.

Values are represented as mean \pm standard deviation 
Table 4. Effect of sub-acute (4 weeks) administration of T. Occidentalis leaves extract on some liver biochemical indices in rats

\begin{tabular}{|c|c|c|c|c|c|c|c|}
\hline \multirow[b]{2}{*}{ INDICES } & \multirow[b]{2}{*}{$\begin{array}{c}\text { GROUP }-1 \\
(\text { CONT ROL }) \\
(\mathrm{n}=5)\end{array}$} & \multicolumn{4}{|c|}{ GROUPS } & \multirow[b]{2}{*}{$\mathrm{F}$} & \multirow[b]{2}{*}{ P-VALUE } \\
\hline & & $\begin{array}{r}\text { GROUP - } 2 \\
(500 \mathrm{mg} / \mathrm{kg})\end{array}$ & $\begin{array}{l}\text { GROUP }-3 \\
(1000 \mathrm{mg} / \mathrm{kg})\end{array}$ & $\begin{array}{l}\text { GROUP }-4 \\
(2000 \mathrm{mg} / \mathrm{kg})\end{array}$ & $\begin{array}{l}\text { GROUP }-5 \\
(4000 \mathrm{mg} / \mathrm{kg})\end{array}$ & & \\
\hline $\operatorname{AST}(\mu / \mathrm{L})$ & $11.92 \pm 1.72$ & $15.18 \pm 1.14$ & $18.00 \pm 0.68$ & $16.56 \pm 0.36$ & $18.36 \pm 0.511$ & 33.18 & $<0.001$ \\
\hline $\operatorname{ALP}(\mu / L)$ & $52.80 \pm 1.79$ & $53.20 \pm 1.48$ & $54.20 \pm 1.30$ & $54.0 \pm 1.87$ & $55.40 \pm 2.61$ & 1.45 & 0.253 \\
\hline $\operatorname{ALT}(\mu / L)$ & $17.21 \pm 0.44$ & $17.92 \pm 0.91$ & $17.21 \pm 0.44$ & $17.20 \pm 0.45$ & $17.93 \pm 0.90$ & 1.71 & 0.188 \\
\hline AST/ALT RATIO & $0.69 \pm 0.11$ & $0.85 \pm 0.04$ & $1.05 \pm 0.04$ & $0.96 \pm 0.02$ & $1.03 \pm 0.05$ & 30.19 & $<0.001$ \\
\hline $\begin{array}{c}\text { TOTAL PROTEIN } \\
\mathrm{g} / \mathrm{L} \\
\end{array}$ & $42.00 \pm 1.58$ & $60.40 \pm 1.14$ & $63.40 \pm 1.81$ & $68.60 \pm 1.52$ & $77.50 \pm 0.85$ & 424.24 & $<0.001$ \\
\hline ALBUMIN g/L & $24.30 \pm 0.42$ & $26.86 \pm 0.17$ & $28.94 \pm 0.09$ & $30.58 \pm 0.91$ & $39.80 \pm 1.30$ & 317.967 & $<0.001$ \\
\hline GLOBULIN g/L & $16.70 \pm 0.44$ & $18.80 \pm 1.64$ & $18.00 \pm 0.71$ & $28.40 \pm 1.14$ & $27.40 \pm 1.14$ & 128.85 & $<0.001$ \\
\hline $\begin{array}{c}\text { ALB/GLOBULIN } \\
\text { RATIO } \\
\end{array}$ & $1.45 \pm 0.05$ & $1.44 \pm 0.13$ & $1.16 \pm 0.06$ & $1.08 \pm 0.05$ & $1.45 \pm 0.05$ & 35.53 & $<0.001$ \\
\hline $\begin{array}{l}\text { TOTAL BIL. } \\
(\mu \mathrm{mol} / \mathrm{L})\end{array}$ & $11.56 \pm 0.44$ & $10.00 \pm 1.22$ & $13.38 \pm 0.57$ & $12.20 \pm 0.76$ & $13.60 \pm 055$ & 18.510 & $<0.001$ \\
\hline CONJ. BIL. $(\mu \mathrm{mol} / \mathrm{L})$ & $3.56 \pm 0.15$ & $4.23 \pm 0.21$ & $3.90 \pm 0.13$ & $4.80 \pm 0.07$ & $5.41 \pm 0.11$ & 130.707 & $<0.001$ \\
\hline BODY WEIGHT g & $165.40 \pm 0.55$ & $164.40 \pm 1.14$ & $165.40 \pm 1.51$ & $164.60 \pm 1.79$ & $160.20 \pm 1.79$ & 14.05 & $<0.001$ \\
\hline LIVER WEIGHT g & $3.40 \pm 1.58$ & $3.28 \pm 0.11$ & $3.77 \pm 0.160$ & $3.84 \pm 0.89$ & $3.78 \pm 0.08$ & 21.33 & $<0.001$ \\
\hline $\begin{array}{c}\text { LIVER WEIGHT / } \\
\text { BODY WEIGHT } \\
\text { RATIO } \\
\end{array}$ & $0.0206 \pm 0.0010$ & $\begin{array}{c}0.0199 \pm \\
0.0006\end{array}$ & $\begin{array}{c}0.0228 \pm \\
0.0010\end{array}$ & $\begin{array}{c}0.0240 \pm \\
0.0005\end{array}$ & $\begin{array}{c}0.0229 \pm \\
0.0006\end{array}$ & 25.55 & $<0.001$ \\
\hline
\end{tabular}

$\mathrm{P}<0.05$ was considered statistically significant

Values are represented as mean \pm standard deviation

\section{Discussion}

Findings of this study showed that there were significant differences in values of AST, AST/ALT ratio, Total protein, Albumin, Globulin, ALB/Gratio, Total body weight, Total and Conjugated bilirubin between control and test groups in both phases of the study. Serum levels of other parameters were statistically non-significant even though the experimental groups recorded higher values than control groups.

The significant changes in the above-mentioned parameters are unlikely to be due to the toxic effect of the extract on liver cells. This is because, of the two major enzy mes (AST \& ALT) usually used as surrogate markers for hepatic injury[32-34], only AST was significantly elevated.

A significant high level of AST and ALT is common in most acute and sub-acute hepatocellular disorders with ALT being higher than or equal to AST. In addition, prior studies have empirically shown that these transaminase enzymes are widely distributed in other cells of the body and the serum levels could be elevated in injury affect ing these cells such as muscle in jury due to strenuous exerc ise, rhabdomyolys is and myositis [35]. Nevertheless, the activities of ALT outside the liver cells are very low and therefore, ALT is considered more specific for hepatocellular damage than AST[36]. Isolated significant increase in AST may have been extrahepatic as this enzyme is also found in other tissue such as kidneys, brain, pancreas, lungs, leukocytes, erythrocytes, cardiac and skeletal muscles[37].

Again, preponderance of emp irical evidences suggest that dietary protein levels could affect the activities of liver enzymes. Koutsos et al[38] demonstrated the effect of various concentrations of dietary protein level on the activity of the liver en zy mes. In this study, it was shown that levels of AST and ALT were increased following a very high concentration of crude protein (70\%) meal. Up-regulation of these liver enzy mes (AST and ALT) involved in a mino acid catabolism is the probably mechanism[38]. This also explains the reason for the highest level of the enzy mes (AST and ALT) in animals in-group five fed with the highest concentration of the extract. It could have also correlated with the extra-hepatic activities of these enzymes.

Raised serum ALP level usually reflects impaired excretion and bile flow as in the obstruction that affects biliary system. Increase serum level may reflect increase synthesis in the phase of inadequate excretion as in conditions leading to increase biliary pressure. In this study, such insignificant increase observed could not have indicated hepatobiliary obstruction; rather extra hepatic sources (e.g. bone) may be implicated[35].

In addition, significant raised levels of serum total protein, albumin, albumin/globulin ratio in this study could further buttressed the non-toxic effect of the extract to the liver. The liver synthesizes protein and low levels could reflect impaired synthesis. Normal level reflects normal synthes is while high level is common in high protein diet. It could therefore be correct to assert that, the significant high levels of serum protein and protein fractions observed in the experimental groups was due to the high protein content of $T O$ leaves extract admin istered at high concentrations to the tested animals. The plausibility of this assertion lends support from several previous studies, which convincingly demonstrated the presence of rich amino acid and protein content of $T O$ leaves extract.

Akoroda[39], in his study showed that $T O$ leaf extract is highly nutritive and is very rich in protein $(21 \%-37 \%)$. Kayode et al[40] made similar observation. In other studies 
the extract of this leaf was emp irically shown to constitute a rich source of an array of amino acids such as alanine, aspartate, glycine, glutamate, histidine, lysine, methionine, tryptophan, cysteine and leucineetc[12, 41], which could provide a readily available precursors for protein synthesis. High amino acid or protein diet is associated with high hepatic synthesis and hence high serum protein[42] as recorded in this study.

In contradistinction to previous studies [13, 43], there was a significant reduction in body weight of the experimental animals in both phases of the study. Prior studies have shown that the health benefits or adverse health effect obtained fro $\mathrm{m}$ consumption of plant food is rooted in the concentration of phytochemicals and nutritional constituents, which are determine by the quantity consumed[44]. Telfiariaoccidetalis leaves meal has severally demonstrated growth stimulating effect with associated weight increase at an optimal threshed concentration of the extract beyond which loss in weight ensued.

Fasuyi et al[13] observed that birds kept on 15\% TO leaves meal dietary inclusion level had the highest weight gained with subsequent weight reduction at doses greater than $15 \%$ extract concentration. Iweala and Obidoa[43] showed that, if the dose of the extract is kept low at a tolerable level, it could be administered or consumed for a longer period without weight loss. Similarly, Saalu et al[44] demonstrated evidence of testicular protective effect in rats treated with dose of $T O$ extract $<400 \mathrm{mg} / \mathrm{kg}$ body weight and testicular toxic effect at concentrations $>$ $400 \mathrm{mg} / \mathrm{kg}$ body weight. It could be correct to infer that the weight loss in this study was associated with the high doses of the extract admin istered to the experimental animals.

Harper et al[45] demonstrated that, an excess level of amino acids is associated with decreased food intake, muscle deposition and loss in body we ight in ch icken and rats. Water intake was also significantly greater in birds fed with very high protein (CP of 70\%) diet signifying the possibility of hyper-osmolar diuresis leading to dehydration and subsequent polydipsia. All these could have contributed to the weight loss associated with high protein diet, which was more significant $(\mathrm{P}<0.001)$ in-group fed with the highest concentration of the extract in both phases of the study. The plausibility of previous findings obtains validity from the present study.

Again, some of biochemical changes noted in this study could have been due to the effect of some of the phytochemical constituents detected. These include saponin, tannin, flavanoids, alkaloids and phenolics. Also present were, hydrogen cyanide, phytate and oxalate. These bioactive constituents have empirically, been shown to possess varied biological effects probably due to their structural differences and concentrations found in different plant species. For example, saponins are steroids and are present in a number of plants and plants products. Prior studies have shown that saponin-containing vegetables have a characteristic bitter taste and foaming properties. They have anti-nutrient properties, are associated with hemolysis, and retard growth because; they primarily cause a reduction in feed intake[46]. Sharma et al[47] observed that 4-7 weeks of adlibitum feeding of saponin containing feed resulted in some toxic manifestations such as listlessness, anorexia, weight loss and gastroenteritis in sheep.

Thus, the presence of saponin compounds as a major constituent in the extract of $T O$ as detected in this study could have contributed to loss in weight, which was more significant $(\mathrm{P}<0.001)$ in-group, fed with the highest concentration of the extract in both phases of the study. Additionally, the significant levels of total and conjugated bilirubin, which signifies hemolytic disorders, could be associated with the effect of saponin as it's known to cause hemolysis of red blood cells especially when used at high concentrations [46].

Tannin another bioactive constituent is a water-soluble polyphenol with anti-in flammatory and anti-microbial effect. It has both bacteriocidal as well as bacteriostatic effect against staph. aureus and other micro-organis ms. Prior studies have shown that the presence of tannins in the extract provides the effect for its use as purgative[21], anti-asthmatic, antitussives and anti-hay fever[19].

Tannin also has some anti-nutrient effect achieved by forming complexes with protein. It binds and inhibits protein such as digestive enzymes[47]. However, the toxicity of tannin depends on the form with which it occurs. Generally, the hydrolysable form is more toxic than the condense form which is more digestible and reducing in effect[47]. The absence of a significant toxic effect in this study could imply that the extract contained predominantly the condense form of tannin. However, the plausibility of this assertion is an area for further research.

Hydrogen cyanide, detected as an anti-nutrient has been shown to be a potentially to xic substance. However, its effect on the liver is very rare. It is absorbed as soon as released and is rapidly detoxified in the liver by the liver enzyme rhodanese which convert cyanide to thiocyanate by catalyzing the transfer of sulfur of thiosulfate to the cyanide to form thiocyanate (a less toxic form) which is excreted in the urine[48,49]. The presence of the extract of $T O$ with its cyanide content is noted to trigger on the activities of rhodanese. The present of the extract also provides the sulfur ions containing amino acid needed to enhance this process. This could explain the low toxicity of cyanide to the liver despite its high concentration in the extract.

Phytic acid structurally represented as $\mathrm{C}_{6} \mathrm{H}_{6}\left[\mathrm{OPO}(\mathrm{OH})_{2}\right]$ is another anti-nutrient detected in $T O$ leaves extract. It is an hexaphosphoric acid ester of inositol. It is naturally stored in plant tissues as calcium and/or magnesium salt[50]. It represents the major storage form of phosphorus and is a strong chelator due to the presence of reactive phosphate groups. Several studies have shown that phytic acid is hepatoprotective in action. Abd-El-Rahaman et al[51] showed that animals treated with phytic acid added meal had a significant reduction in levels of some liver en zy mes (AST \& ALT) (evidence of hepatoprotective effect) against significant increases levels in those treated with Aflotoxin B 
(evidence of hepatotoxicity). There were also significant increases in serum total biliribin, protein, albumin, caspase-3-transferase and glutathione-S-trans ferase levels.

Shibata[50] showed that there were no significant differences in levels of total protein, albumin to globulin ratio, AST, ALT between broilers treated with phytic acid added meal than control. However, abdominal fat weight reduction was noted in experimental than control groups. This reduction was proportional to the quantity of phytic acid added.

The present study results are congruent with the above mentioned and go further to support the fact that most of the phytochemical constituents of Telfiariaoccidentalisare not hepatotoxic, but could enhance some other physiological changes e.g. weight loss, raised protein levels, mild hemolysisetc as detected in this study.

The hepatoprotective effect as observed in this study stand in clear support to previous studies with similar documentations.

\section{Conclusions}

The result of this study showed that the extract of Telfairiaoccidentalis is not toxic to the liver even at very high doses.

\section{REFERENCES}

[1] Inoue H, Yamazaki S, Shimizu M, Uozaki H, Goto T, Ohnishi S, Koike K. Liver injury induced by the Japanese Herbal Drug Kamishoyosan. Gastroenterology and Hepatology, 7(10):692-694, 2011.

[2] Peyton BG, Spears TL, Lindsey A. A survey of the use of herbal medicine in patients with hepatitis C. Hepatology, 30: A191, 1999.

[3] Chitturi S, Farrell GC. Herbal hepatotoxicity: an expanding but poorly defined problem. Journal of Gastroenterology and Hepatology, 15:1093-1099, 2000.

[4] Haller CA, Dyer JE, Ko R, Olson K. Making a diagnosis of herbal related toxic hepatitis. Western Journal of Medicine, 176 (1):39-44, 2002.

[5] Cunningham AB. An investigation of herbal medicine trade in Natal/Kwazulu Investigation report No 29. Institute of National Resources, 1988.

[6] Sheikh NM, Philen RM, Love LA. Chaparral-associated hepatotoxicity. Archives of Internal Medicine, 157:913-919, 1997.

[7] Smith AY, Feddersen RM, Garner Jr KD. Cystic renal cell carcinoma and acquired renal cystic disease associated with consumption of chaparral tea: A case report. Journal of Urology, 152:2089-2091, 1994.

[8] Picciotti A, Campo N, Brizzolara R. Chronic hepatitis induced by Jin Bu Huan. Journal of Hepatology, 28:165-167, 1998.

[9] Pak E, Esrason KT, Wur H. Hepatoxicity of herbal remedies: an emerging dilemma. ProTransplant, 14 (2): 91-96, 2004

[10] Lee AU, Farrel GC. Drug-induced liver disease. Current Opinion in Gastroenterology, 13:199-205, 1997.

[11] Hruby K, Cosmos G, Fuhrmann M, Thaler H. Chemotherapy of Amanita phalloides poisoning with intravenous silibinin. Human \& Experimental Toxicology, 2:183-195, 1983.

[12] Tindall, HD. Commercial Vegetable Growing, $1^{\text {st }}$ ed., Oxford University Press Oxford, UK, p543, 1968.

[13] Fasuyi AO, Nonyerem AD. Biochemical, nutritional and haematogical implications of Telfairiaoccidentalisleaf meal as protein supplement in broiler starter diets. African Journal of Biotechnology, 6:1055-1063, 2007.

[14] Alada, AR. The haematological effect of Telfairiaoccidentalisdiet preparation. African Journal of Biomedical Research, 3:185-186, 2000.

[15] Ajayi AI, Ajayi TC, Omoaro EU, Halim NK. Erythropoietic value of pumpkin leaf extract in rabbits - a preliminary study. Nigerian Journal of Phy siological Sciences, 16: 1-3, 2000.

[16] Oluwole FS, Falode AO, Ogundipe OO. Anti-inflammatory effect of some common Nigerian Vegetables. Nigerian Journal of Phy siological Sciences, 18:35-38, 2003.

[17] Eseyin OA, Ebong P, Ekpo A, Igboasoiyi, A Oforah, E. Hypoglycemic effect of the seed extract of Telfairiaoccidentalisin rats. Pakistan Journal of Biological Sciences, 10:498-501, 2007.

[18] Eseyin OA, Ebong P, Eyong E, Awofisayo O, Agboke, A. Effect of Telfairiaoccidentalison oral glucose tolerance in rats. African Journal of Pharmacy and Pharmacology, 4 (6): 368-372, 2010

[19] Gills LS. Ethnomedical uses of plants in Nigeria. University of Benin Press, Benin City, Nigeria, p. 276, 1992.

[20] Khalid SA, Duddeck H, Gonzalez-Sierva M. Isolation and characterization of an anti malarial agent of the neem tree Azadirachtaindica. Journal of Natural Products, 52:922-926, 1989.

[21] Adeniyi SA, Orijiekwe CL, Ehiagbonare, JE, Arimah BD. Preliminary phytochemical analysis and insecticidal activity of ethanolic extracts of four tropical plants (Vernoniaamygdalina, Sidaacuta, Ocimumgratissimum and Telfairiaoccidentalis) on beans weevil (Acanthscelidesobetectus). International Journal of Physical Sciences, 5(6):753-762, 2010.

[22] Trease GE, Evans WC. A Textbook of Pharmacognosy, $13^{\text {th }}$ ed., Baluiere, Tindali, London, pp. 100-101, 1989.

[23] Sofowara A. Medicinal plant and traditional medicine in Africa. $2^{\text {nd }}$ ed., Spectrum Books, Ibadan Nigeria, pp 112, 1996.

[24] Makkar AS, Goodchild AV. Quantification of Tannins. A Laboratory Manual. International Center for Agriculture Research in the Dry Areas (ICARDA), Aleppo, Syria IV, p 25, 1996.

[25] Young SM, Greaves JS. Influences of variety and treatment 
on phytic acid content of wheat. Food Research International, 5:103-105.

[26] Moir KW. The determination of oxalic acid in plants. Queenland Journal of Agricultural and Animal Sciences, 10(1):1-3, 1953.

[27] Ranjhan SR, Krishna G. In laboratory manual for Nutrition Research, eds, Ranjhan SR \& G. Krishna. Viskas Pub. Co, New Dehli,india,

[28] Lorke D. A new approach to practical acute toxicity testing. Archives of Toxicology, 54:275-287, 1983.

[29] Segal HL, Matsuzawa T. L-Alanine aminotransferase (rat liver). Methods in Enzymology 17A: 153-159, 1970.

[30] Ahamed Z, King EJ. Kinetics and placental alkaline phosphatase. Biochimica et BiophysicaActa, 34:313, 1959.

[31] Doumas BT, Watson WA, Biggs HG. Albumin standard and measurement of serum-albumin with bromocresol green. ClinicaChimicaActa, 31; 87, 1971.

[32] Liz H. Monitoring test for people with HIV-Liver function test. Bulletin of Experimental treatment for AIDS,2003.http://www.aegis.com/pubs/beta/2003/be030703 $\mathrm{html}$

[33] Svetlovet SL, Xiang Y, Oli MW, Foley DP, Huang G, Hayes RL, Ottens AK, Wang KW. Identification and preliminary validation of novel biomarkers of acute hepatic Ischemia/reperfusion injury using dual platform proteomic/degradomic approaches. Biomarkers, 11(4):355-369, 2006.

[34] Dobbs NA, Twelves CJ, Gregory W, Cruickshanka C, Richards MA, Rubens RD. Epirubicin in pathient with liver dysfunction development and evaluation of a novel dose modification scheme. European Journal of Cancer, 39: 580-586, 2003

[35] Hasan FA, Owyed S. Interpretation of liver chemistry test. Bulletin of the Kuwait Institute for Medical Specialization, 2: 27-31, 2003.

[36] Emeka EJ, Obidoa O. Effect of a long-term consumption of a diet supplement with leaves of GongeronemalatifoliumBenth, on some biochemical and histological parameters in male albino rats. Journal of Biological Sciences, 9 (9): 859-865, 2009.

[37] Kasper DL, Fauci AS, Longo DL, Jameson JL, Hauser SL, Braunwald E (Editors). Harrison's Principles of Internal Medicine, 16th ed., MoGraw- Hill Medical Publishing Division, New York,2005.

[38] Koutsos EA, Smith J, Woods LW, Klasing KC. Adult cockatiels (Nymphicushollandicus) metabolically adapt high protein diets. Journal of Nutrition, pp 118-122, 2001.
[39] Akoroda MO. Seed production and breeding potential of fluted pumpkin,Telfairiaoccidentalis. Euphytica, 49 (1): 25-32, 1990.

[40] Kayode AA, Kayode OT. Some medicinal values of Telfairiaoccidentalis: A review. American Journal of Biochemistry and Molecular Biology, 1:30-38, 2010.

[41] Fasuyi AO. Nutritional potentials of some tropical vegetable leaf meals: Chemical characterization and functional properties. African Journal of Biotechnology, 5: 49-53, 2006.

[42] Yakubu MT, Bilbis LS, Lawal M, Akanji MA. Evaluation of selected parameters of rat liver and kidney function following repeated administration of Yohimbine. Biokemistri, 15 (2):50-56, 2003.

[43] Iweala EJ, Obidoa O. Some biochemical, haematological and histological responses to a long term Consumption of Telfairiaoccidentalis- supplemented diet in rats. Pakistan Journal of Nutrition, 8(8):1199-1203, 2009.

[44] Saalu LC, Kpela T, Benebo AS, Oyewopo AO, Anifowope, EO, Oguntola JA. The Dose-dependent testiculoprotective and testiculotoxic potentials of Telfairiaoccidentalis Hook $f$. leaves extract in rat. International Journal of Applied Research in Natural Products, 3(3):27-38, 2010.

[45] Harper AE, Benevenga NJ, Wohlhueter RM. Effects of ingestion of disproportionate amounts of amino acids. Physiology Reviews, 50: 428-471, 1970.

[46] Shqueir AA, Brown DL, Taylor SJ, Rivkin I, Klasing KC Effects of solvent extraction, heat treatment and added cholesterol on SesbaniaSesban toxicity in growing chicks. Animal Feed Science and Technology, 27:127-135, 1989.

[47] Kumar R, Sigh M. Tannins: their adverse role in ruminant nutrition. Journal of Agriculture and Food Chemistry, 32: 447-453, 1984

[48] Salkowski A, Penney D. Cyanide poisoning in animals and humans: a review. Veterinary \& Human Toxicology, 36 (5): 455-466, 1994.

[49] Herbert C. NTP Technical Report on Toxicity of Sodium Cyanide, North Carolina: National Toxicology Program 1993. Toxicity Report Series Number 37, NIH Publication 94-3386, 1993.

[50] Shibata T, Yoneda K, Araki T, Nikki T. Effect of phytic acid dietary level on growth performance and serum compound in broiler chicken. Journal of Poultry Sciences, 49: 111-115, 2012.

[51] Al-Rahman AA, Abd EC-Naem GF, EL-Shafei M, EL-Morsi. Effect of phytic acid on liver and kidneys weight and some Biochemical parameters in Albino rats treated with Aflaxo xin B. African Crop Science Proceedings, 8: 1765-1772, 2007. 